King, E. J. (1932). Biochem. F. 26, 292.

McCance, R. A. \& Shipp, H. L. (1933). Spec. Rep. Ser. med. Res. Coun., Lond., no. 187.

McCance, R. A., Widdowson, E. M. \& Shackleton, L. R. B. (1936). Spec. Rep. Ser. med. Res. Coun., Lond., no. $2 \mathrm{I} 3$.

Passmore, R., Meiklejohn, A. P., Dewar, A. D. \& Thow, R. K. (1955). Brit. f. Nutr. 9, 27.

Stanier, M. W. (1957). Brit. F. Nutr. I1, 206.

Trowell, H. C., Davies, J. N. P. \& Dean, R. F. A. (1954). Kwashiorkor. London: Edward Arnold.

\title{
Effect of protein deficiency and subsequent refeeding on body composition of adult rats
}

\author{
BY MARGARET W. STANIER \\ Medical Research Council Department of Experimental Medicine, University o, \\ Cambridge
}

(Received I9 November 1956)

The experiments reported in this paper were undertaken in consequence of some observations made on human subjects in East Africa (Holmes, Jones, Lyle \& Stanier, I956). Poorly nourished Africans appeared to have an increase not only of extracellular fluid but also of the intracellular fluid of the body. Moreover, when such poorly nourished African men were given a good diet, the tissue gain calculated from the observed nitrogen retention (by assuming that the soft tissues consist of $33 \%$ protein) bore no relation to the observed change in body-weight (Holmes, Jones \& Stanier, I954). Although the subjects lost extracellular water (oedema fluid) while taking the good diet, this loss was quantitatively inadequate to account for the anomalous changes in body-weight. A possible explanation of the anomaly is that in severe protein deficiency the cells contain less than the normal concentration of protein and an excess of intracellular fluid; and that during good feeding a simultaneous loss of intracellular water (or fat) might mask the effect on the total body-weight of a gain of intracellular protein.

Although increase of extracellular fluid is a well-known accompaniment of undernutrition, increase of intracellular fluid has seldom been observed. Neither Keys's group in the United States (Keys, Brožek, Henschel, Mickelsen \& Taylor, I950) nor McCance's group in Germany (Widdowson \& McCance, 195I) found such an increase; but it has been suggested that an increase of intracellular fluid may occur in severely undernourished persons in southern India (Gopalan, Venkatachalam \& Srikantia, I953). It is possible that such a change of composition of tissue cells might be a characteristic, not of undernutrition in general, but of the particular type of malnutrition commonly found in Africa and in other underdeveloped regions: a protein deficiency without a corresponding calorie deficiency.

When young growing rats were fed for 2 weeks on a diet very low in protein, and then refed on an adequate diet, there was no apparent change in the composition of the 
tissues (except for liver tissue) before and after the refeeding (Widdowson \& McCance, 1957). The duration of the experiments was limited because the young rats were able to survive for only a short time on the low-protein diet, and the controls for an even shorter time on a high-protein, low-calorie diet. The present paper reports the results of a similar experiment made on adult rats kept for about 2 months on a diet resembling that of many adult Africans, in order to find whether such a diet could alter the composition of these animals' tissues.

\section{EXPERIMENTAL}

Animals and diets. Thirty adult male rats, $4-8$ months old and about $300 \mathrm{~g}$ in weight, were divided into three groups of roughly equal weight. The animals of group A were placed on a diet containing cassava flour or tapioca flakes, $250 \mathrm{~g}$, and mashed banana, I $25 \mathrm{~g}$, with water to about $700 \mathrm{~g}$. Protein provided about $\mathrm{I} \cdot 3 \%$ of the dry weight of the food. This 'low-protein' diet was offered in unlimited amounts and the animals ate enough of it to provide them with 50-70 Cal./day, the calorie intake appropriate to a $300 \mathrm{~g}$ rat. The animals of group B received a diet containing equal parts of dried skim milk and fish meal, with water to mix it. Protein made up about $50 \%$ of the dry weight of the food. The rats were given this diet in limited amounts such that the mean body-weight ran parallel with that of the animals in group $A$. This diet will be referred to as the 'high-protein, low-calorie' diet. The animals of group $\mathrm{C}$, the controls, received ad lib. equal amounts of the diet of group A and group B ('control mixture' diet). All animals received a salt mixture and vitamin B-complex powder daily. After the first 4 weeks all animals received $\mathrm{I}-2 \mathrm{~g}$ of cabbage leaf twice a week as a source of carotene. During refeeding, all animals received ad lib. the diet of the control animals (i.e. a I: $\mathrm{r}$ mixture of the low-protein and high-protein diets). The animals of groups $\mathrm{A}$ and $B$ were kept in individual cages, and body-weight and food consumption of each animal were recorded daily. The $\mathrm{N}$ content of each of the foodstuffs was measured as was also the fat content of the fish meal, the only item which contained appreciable amounts of fat.

Procedure. When the rats had been fed for about 60 days on the diets described, and the animals of groups A and B had lost about $30 \%$ of their initial body-weight, half the animals in each of the three groups were killed by an overdose of the anaesthetic Nembutal (Abbott Laboratories Ltd). Samples of skin, skeletal muscle and liver were taken for analysis. These tissues were chosen because the muscles and skin form a large proportion by weight of the soft tissues of the body; so they are the only tissues whose change in composition could make an appreciable difference to the composition of the body as a whole. The liver was investigated because it is the largest organ of the body whose composition is known to be readily altered by diet. The whole residue of the carcass was also weighed, dried and analysed. The remaining animals of all groups were then fed ad lib. on the control diet. Those in groups A and B were killed and their tissues analysed when they had regained their initial body-weight, and the remainder of the group $\mathrm{C}$ animals were killed at the same time.

Chemical methods. Water and ash: Samples of tissue taken from each animal were pooled according to its group, and were finely chopped with scissors and placed in 
tared silica crucibles. The tissue was weighed at once, and again after drying in an oven at $105^{\circ}$. The dry matter was ashed in a furnace at $400^{\circ}$. The carcasses were dried to constant weight on tared trays in an oven at $105^{\circ}$.

Nitrogen: Samples of finely-chopped tissue weighing about $2 \mathrm{~g}$ were weighed in tared screw-cap bottles, covered with strong sulphuric acid and warmed gently in an oven. When the mass was liquid it was made up to $25 \mathrm{ml}$. with strong sulphuric acid. Samples of this solution were taken for estimation of $\mathrm{N}$ by the micro-Kjeldahl method.

Potassium: The ash from the silica crucibles in which the samples of tissue had been dried was taken up in warm conc. $\mathrm{HCl}$, and made to $50 \mathrm{ml}$. in a volumetric flask. Samples of this solution were taken for estimation of $\mathrm{K}$ by the Kramer \& Tisdall method as modified by McCance \& Shipp (1933).

Chloride: Weighed samples of finely chopped tissue were extracted with water and the chloride was estimated by Volhard's method, as described by McCance \& Shipp (i933).

Fat: The fat content of the carcasses was estimated by soaking the dried carcasses for a few days in several changes of light petroleum, b.p. $40-60^{\circ}$, until the petroleum extract had only a trace of yellow colour. The extract was placed in a tared distillation flask, the light petroleum was distilled off and the residue in the flask was weighed. The defatted carcasses were dried to constant weight and reweighed. The mean of the weight loss of the carcasses during defatting and the weight of the material extracted by the light petroleum was taken as the fat content of the carcasses.

\section{RESULTS}

As the conditions of the experiment were intended to reproduce as closely as possible the conditions of the human subjects studied by Holmes et al. (1954), Table I shows the percentage of total calories obtained from protein by the various groups of rats and by the human subjects as calculated from the data of Holmes et al. It will be seen that as to dietary protein the rats of group A were rather worse off than the men, and that during refeeding the rats were a little better off than the best fed of the patients of Holmes et al.

Table I. Percentage of total calories obtained from protein by the African subjects of Holmes et al. (1954) and by the rats in this experiment

$\begin{array}{lc}\text { Africans: before refeeding } & 6^{*} \\ \text { during refeeding } & \text { 1 1-22* } \\ \text { Rats on low-protein diet (group A) } & \text { I.5 } \\ \text { Rats on high-protein, low-calorie diet } & 44 \\ \text { (group B) } & \\ \text { Control rats (group C) and groups A } & 25 \\ \text { and B during refeedingt }\end{array}$

* Calculated from data of Holmes et al. (1954).

$\dagger$ All on a I:I mixture of the low-protein and the high-protein, low-calorie diets.

The results of the analysis of the rat tissues at the end of feeding the experimental diet, and at the end of the refeeding period, are given in Tables 2-4. 
From Table 2 it can be seen that after the experimental diet the muscles, skin and whole carcass of both experimental groups contained a greater percentage of water than those of the control animals. After the period of refeeding there was a decrease in the water content of the skin, muscle and whole carcass of all animals. However, calculated on the basis of the fresh fat-free carcass weight, the water content was almost identical in the three groups and was scarcely changed during refeeding.

Table 2. Water and nitrogen content of tissues and carcasses of adult rats after the feeding of experimental diets and after refeeding on the control diet

(Mean values for groups of five rats)

\begin{tabular}{|c|c|c|c|c|c|c|}
\hline \multirow[b]{2}{*}{ Group } & \multirow[b]{2}{*}{ Experimental diet } & \multirow[b]{2}{*}{ Material } & \multicolumn{2}{|c|}{$\begin{array}{l}\text { After the feeding of } \\
\text { experimental diet }\end{array}$} & \multicolumn{2}{|c|}{ After refeeding } \\
\hline & & & $\begin{array}{l}\text { Water }(\mathrm{g} / \mathrm{I} 00 \mathrm{~g} \\
\text { fresh weight) }\end{array}$ & $\begin{array}{l}\text { Nitrogen } \\
\text { (g/roog fresh } \\
\text { weight) }\end{array}$ & $\begin{array}{l}\text { Water (g/100 } \mathrm{g} \\
\text { fresh weight) }\end{array}$ & $\begin{array}{l}\text { Nitrogen } \\
\text { (g/roo g fresh } \\
\text { weight) }\end{array}$ \\
\hline A & Low-protein & $\begin{array}{l}\text { Muscle } \\
\text { Liver } \\
\text { Skin } \\
\text { Carcass } \\
\text { Fat-free } \\
\text { carcass }\end{array}$ & $\begin{array}{l}77 \cdot 3 \\
67 \cdot 3 \\
62 \cdot 2 \\
65 \cdot 5 \\
71 \cdot 0\end{array}$ & $\begin{array}{l}3 \cdot 18 \\
2 \cdot 08 \\
4.68 \\
2 \cdot 90 \\
3 \cdot 15\end{array}$ & $\begin{array}{l}72 \cdot 3 \\
71 \cdot 9 \\
55 \cdot 8 \\
64 \cdot 0 \\
71 \cdot 0\end{array}$ & $\begin{array}{l}3 \cdot 12 \\
3 \cdot 32 \\
3 \cdot 53 \\
3 \cdot 12 \\
3 \cdot 46\end{array}$ \\
\hline B & $\begin{array}{l}\text { High-protein, } \\
\text { low-calorie }\end{array}$ & $\begin{array}{l}\text { Muscle } \\
\text { Liver } \\
\text { Skin } \\
\text { Carcass } \\
\text { Fat-free } \\
\text { carcass }\end{array}$ & $\begin{array}{l}76 \cdot 4 \\
72 \cdot 1 \\
65 \cdot 9 \\
68 \cdot 3 \\
70 \cdot 2\end{array}$ & $\begin{array}{l}3 \cdot 27 \\
3 \cdot 42 \\
4 \cdot 40 \\
3 \cdot 14 \\
3 \cdot 25\end{array}$ & $\begin{array}{l}72 \cdot 0 \\
72 \cdot 1 \\
47 \cdot 6 \\
63 \cdot 2 \\
72 \cdot 0\end{array}$ & $\begin{array}{l}3 \cdot 18 \\
3 \cdot 08 \\
3 \cdot 61 \\
3 \cdot 32 \\
3 \cdot 68\end{array}$ \\
\hline C & 'Control mixture'* & $\begin{array}{l}\text { Muscle } \\
\text { Liver } \\
\text { Skin } \\
\text { Carcass } \\
\text { Fat-free } \\
\text { carcass }\end{array}$ & $\begin{array}{l}75 \cdot 1 \\
73 \cdot 8 \\
42 \cdot 0 \\
63 \cdot 0 \\
72 \cdot 8\end{array}$ & $\begin{array}{l}3 \cdot 3 \mathbf{I} \\
3 \cdot 28 \\
2 \cdot 38 \\
2 \cdot 77 \\
3 \cdot 20\end{array}$ & $\begin{array}{l}70 \cdot 4 \\
72 \cdot 4 \\
39 \cdot 3 \\
58 \cdot 2 \\
71 \cdot 0\end{array}$ & $\begin{array}{l}2 \cdot 86 \\
2 \cdot 97 \\
3 \cdot 66 \\
2 \cdot 65 \\
3 \cdot 22\end{array}$ \\
\hline
\end{tabular}

* A I : I mixture of the low-protein and the high-protein diets.

Table 3. Percentage of fat in carcasses of adult rats after the feeding of experimental diets and after refeeding on the control diets

(Mean values for groups of five rats)

$\begin{array}{cccc}\text { Group } & \text { Experimental diet } & \begin{array}{c}\text { After the feeding of } \\ \text { experimental diet }\end{array} & \begin{array}{c}\text { After refeeding } \\ \text { A }\end{array} \\ \text { B } & \begin{array}{c}\text { Low-protein } \\ \text { High-protein, low- } \\ \text { calorie }\end{array} & 8.0 & 10.2 \\ \text { C } & \text { 'Control mixture'* } & 2.5 & 10.1 \\ & * \text { A I : I mixture of the low-protein and the high-protein diets. }\end{array}$

The $\mathrm{N}$ concentrations showed little variation except for the low value in the livers of the animals of group A (protein-deficient) and its increase during refeeding. On the assumption that $\mathrm{N} \times 6.25=$ protein, the sum of the water and protein content of the livers of the protein-deficient animals comprised only about $80 \%$ of the total weight 
Table 4. Chloride content and N:K ratio of tissues and carcasses of adult rats after the feeding of experimental diets and after refeeding on the control diet

(Mean values for groups of five rats)

\begin{tabular}{|c|c|c|c|c|c|c|}
\hline \multirow[b]{2}{*}{ Group } & \multirow[b]{2}{*}{ Experimental diet } & \multirow[b]{2}{*}{ Material } & \multicolumn{2}{|c|}{$\begin{array}{l}\text { After the feeding of } \\
\text { experimental diet }\end{array}$} & \multicolumn{2}{|c|}{ After refeeding } \\
\hline & & & $\begin{array}{l}\text { Chloride } \\
(\mathrm{mg} / 100 \mathrm{~g})\end{array}$ & Ratio, $\mathrm{N}: \mathrm{K}$ & $\begin{array}{c}\text { Chloride } \\
(\mathrm{mg} / \mathrm{r} \text { (0) g) }\end{array}$ & Ratio, N:K \\
\hline$A$ & Low-protein & $\begin{array}{l}\text { Muscle } \\
\text { Liver } \\
\text { Skin } \\
\text { Carcass }\end{array}$ & $\begin{array}{l}119 \\
126 \\
278 \\
-\end{array}$ & $\begin{array}{r}8 \cdot 3 \\
6 \cdot 2 \\
34 \cdot 6 \\
15 \cdot 4\end{array}$ & $\begin{array}{r}61 \\
\text { II } 4 \\
\text { I } 43 \\
-\end{array}$ & $\begin{array}{r}8 \cdot 2 \\
9 \cdot 5 \\
25 \cdot 2 \\
11 \cdot 5\end{array}$ \\
\hline $\mathrm{B}$ & $\begin{array}{l}\text { High-protein, low- } \\
\text { calorie }\end{array}$ & $\begin{array}{l}\text { Muscle } \\
\text { Liver } \\
\text { Skin } \\
\text { Carcass }\end{array}$ & $\begin{array}{r}90 \\
163 \\
249 \\
-\end{array}$ & $\begin{array}{r}7.8 \\
9.0 \\
33.0 \\
13.0\end{array}$ & $\begin{array}{r}50 \\
120 \\
157 \\
-\end{array}$ & $\begin{array}{r}8 \cdot 4 \\
9 \cdot 0 \\
30 \cdot 2 \\
12 \cdot 7\end{array}$ \\
\hline $\mathrm{C}$ & 'Control mixture'* & $\begin{array}{l}\text { Muscle } \\
\text { Liver } \\
\text { Skin } \\
\text { Carcass }\end{array}$ & $\begin{array}{r}77 \\
142 \\
175 \\
-\end{array}$ & $\begin{array}{r}7 \cdot 4 \\
8 \cdot 3 \\
19 \cdot 6 \\
I x \cdot 5\end{array}$ & $\begin{array}{r}54 \\
\text { I } 20 \\
108 \\
-\end{array}$ & $\begin{array}{r}7 \cdot 0 \\
8 \cdot 7 \\
30 \cdot 6 \\
10 \cdot 2\end{array}$ \\
\hline
\end{tabular}

* A I : I mixture of the low-protein and the high-protein diets.

after the experimental diet, but $92 \%$ after refeeding. 'This finding suggests a high liverfat concentration brought about by the low-protein diet and its diminution during refeeding; but liver fat was not directly measured.

From Table 3 it will be seen that the carcasses of the protein-depleted animals had a little less, and those of the calorie-deficient animals much less, fat than those of the control animals. After refeeding, the fat of both the low-protein and the low-calorie groups reached about $10 \%$ of the body-weight. The increase in the fat content of the control animals during this time was that normal for ageing rats.

Table 4 shows that in all three groups there was little difference in the $\mathrm{N}: \mathrm{K}$ ratios after the experimental diets and after refeeding, except for the increase during refeeding in the liver tissue of the animals that had received the low-protein diet. The chloride content of the muscles after the feeding of the deficient diets was greatest in the low-protein group and least in the controls, the low-calorie group being intermediate; this sequence was the same as that found for the water concentration of muscles.

\section{DISCUSSION}

In several parts of the world, studies are now being made of the composition of the body and tissues of human infants with kwashiorkor, and also of adults in whom the primary defect had been a lack of dietary protein. It would therefore be convenient to find an experimental animal in which a low-protein diet would produce a characteristic change in composition of the body, a change different from that produced by general undernutrition. The experiment described here was designed to find out whether the tissues of rats would undergo such a change and, in particular, whether the intracellular hydration that may occur in man in this condition could be produced in rats. 
In general, the effect on these adult rats of a diet very low in protein was not very different from that of a calorie deficiency on a high-protein diet. In each there was some hydration of the body as a whole, and of muscles and skin in particular, in comparison with the controls; but there was no reason for supposing that the excess water was intracellular in either. The differences in body fat were to be expected, as it is well known that a low-calorie diet will rapidly deplete the depot fat of the body. Only in the liver did the protein-deficient diet have an effect different from that shown when the deficiency was primarily of calories-a marked lowering of the nitrogen concentration. This again is the usual finding in experimental animals.

Although it is well known that the percentage of protein in the liver can be altered by diet, it is not generally considered to be true for muscle. The usual view is that in the muscular wasting caused by undernutrition or protein deficiency, the muscle cell shrinks, losing water and potassium as well as protein; so the intracellular concentration of protein does not change, or it may slightly increase, if water is lost faster than protein. However, it has recently been suggested (Holmes et al. 1956), on the basis of observations on man, that protein may be lost from cells without water or $\mathrm{K}$; these may even increase. According to the first view the $\mathrm{N}: \mathrm{K}$ ratio is very little changed, or it may slightly increase; according to the second, malnutrition would cause a decrease in the $\mathrm{N}: \mathrm{K}$ ratio. Table 4 shows that in no tissue except the liver did protein depletion cause a decrease in the $N: K$ ratio. For the muscles the $N: K$ ratios were very similar in all three groups and were scarcely altered during refeeding. This finding argues against the idea of an intracellular hydration of muscle during protein depletion.

The percentage of solids in muscle increased during the period of refeeding. But during this time there was also an increase in the control animals which had received the same diet throughout the experiment. It was, therefore, probably not the direct result of the refeeding but the effect of increasing age. The fact that the fat-free carcass showed no increase in percentage of solids during this period suggests that the increase observed in muscle tissue may be largely due to fat.

An interesting small point of difference from the results of Widdowson \& McCance (1957) obtained on young rats is found in the muscle-chloride concentrations. For the young rats, it was the high-protein, low-calorie group that was the most 'undernourished' as judged by the amount of extracellular fluid, of which muscle chloride is a reflection; whereas in the adult rats described here, it is the low-protein group that was the most 'undernourished' by this criterion. The reason for this difference is unknown.

The experiment described in this paper does not vitiate the conclusions drawn from observations on man. It merely suggests that even if a low-protein diet produces in man a characteristic change in body composition different from that produced by general undernutrition, such a characteristic change cannot readily be produced in adult rats.

\section{SUMMARY}

I. The composition of muscle, liver, skin and carcass of groups of ten adult rats was investigated after feeding for 62 days on (A) a diet very low in protein but adequate in other respects, (B) a high-protein diet limited in quantity to maintain the animals at 
the same weight as those of group A, (C) a I : I mixture of diets A and B in unlimited amount. The composition of the rats' tissues and carcasses was studied again after the animals on diets $\mathrm{A}$ and $\mathrm{B}$ had been refed on $\operatorname{diet} \mathrm{C}$ to regain their original body-weight.

2. Diet A reduced the percentage of nitrogen in the liver but did not affect the other tissues, or the body as a whole, as judged by the nitrogen:potassium ratio. Although animals on diets $A$ and $B$ lost the same amount of weight, the animals on $\operatorname{diet} A$ lost a much smaller percentage of fat than those on diet B.

3. Refeeding after diet $A$ led to an increase in the $N$ concentration and $N: K$ ratio of liver tissue, but not of other tissues. Refeeding after diet B caused great increase in body fat. During refeeding after both diets, there was a decrease in chloride concentration of all three tissues.

I am grateful to the Misses P. and S. Pledger and Miss R. Lowings for valuable technical assistance.

\section{REFERENCES}

Gopalan, C., Venkatachalam, P. S. \& Srikantia, S. F. (I953). Metabolism, 2, 335.

Holmes, E. G., Jones, E. R., Lyle, M. D. \& Stanier, M. W. (1956). Brit. Y. Nutr. ro, I 98.

Holmes, E. G., Jones, E. R. \& Stanier, M. W. (1954). Brit. F. Nutr. 8, I73.

Keys, A., Brožek, J., Henschel, A., Mickelsen, O. \& Taylor, H. L. (1950). The Biology of Human Starvation, Vol. I, p. 273. Minnesota: University Press.

McCance, R. A. \& Shipp, H. L. (1933). Spec. Rep. Ser. med. Res. Coun., Lond., no. 187.

Widdowson, E. M. \& McCance, R. A. (1951). In Spec. Rep. Ser. med. Res. Coun., Lond., no. 275, p. I65.

Widdowson, E. M. \& McCance, R. A. (1957). Brit. F. Nutr. II, 198. 